\title{
Complete genome sequence of Marinobacter adhaerens type strain (HP15), a diatom-interacting marine microorganism
}

\author{
Astrid Gärdes' ${ }^{1}$ Eva Kaeppel ${ }^{1}$, Aamir Shehzad ${ }^{1}$, Shalin Seebah ${ }^{1}$, Hanno Teeling ${ }^{2}$, Pablo \\ Yarza $^{3}$, Frank Oliver Glöckner ${ }^{2}$, Hans-Peter Grossart ${ }^{4}$ and Matthias S. Ullrich ${ }^{1 *}$ \\ ${ }^{1}$ Jacobs University Bremen, School of Engineering and Science, Bremen, Germany \\ ${ }^{2}$ Max Planck Institute for Marine Microbiology, Microbial Genomics and Bioinformatics \\ Group, Bremen, Germany \\ ${ }^{3}$ Institut Mediterrani d'Estudis Avançats, Marine Microbiology Group, Esporles, Spain \\ ${ }^{4}$ IGB-Neuglobsow, Dept. Limnology of Stratified Lakes, Stechlin, Germany \\ * Corresponding author: Matthias S. Ullrich (m.ullrich@jacobs-university.de)
}

Keywords: marine heterotrophic bacteria, diatoms, attachment, marine aggregate formation

Marinobacter adhaerens HP15 is the type strain of a newly identified marine species, which is phylogenetically related to $M$. flavimaris, M. algicola, and $M$. aquaeolei. It is of special interest for research on marine aggregate formation because it showed specific attachment to diatom cells. In vitro it led to exopolymer formation and aggregation of these algal cells to form marine snow particles. M. adhaerens HP15 is a free-living, motile, rod-shaped, Gramnegative gammaproteobacterium, which was originally isolated from marine particles sampled in the German Wadden Sea. M. adhaerens HP15 grows heterotrophically on various media, is easy to access genetically, and serves as a model organism to investigate the cellular and molecular interactions with the diatom Thalassiosira weissflogii. Here we describe the complete and annotated genome sequence of $M$. adhaerens HP15 as well as some details on flagella-associated genes. $M$. adhaerens HP15 possesses three replicons; the chromosome comprises 4,422,725 bp and codes for 4,180 protein-coding genes, 51 tRNAs and three rRNA operons, while the two circular plasmids are $\sim 187 \mathrm{~kb}$ and $\sim 42 \mathrm{~kb}$ in size and contain 178 and 52 protein-coding genes, respectively.

\section{Introduction}

Strain HP15 (DSM 23420) is the type strain of the newly established species Marinobacter adhaerens sp. nov. and represents one of 27 species currently assigned to the genus Marinobacter [1]. Strain HP15 was first described by Grossart et al. in 2004 [2] as a marine particle-associated, Gramnegative, gammaproteobacterium isolated from the German Wadden Sea. The organism is of interest because of its capability to specifically attach in vitro to the surface of the diatom Thalassiosira weissflogii-inducing exopolymer and aggregate formation and thus generating marine snow particles [3]. Marine snow formation is an important process of the biological pump, by which atmospheric carbon dioxide is taken up, recycled, and partly exported to the sediments. This sink of organic carbon plays a major role for marine biogeo- chemical cycles [4]. Several studies reported on the formation and properties of marine aggregates [5-8]. Although it was shown that heterotrophic bacteria control the development and aggregation of marine phytoplankton [3], specific functions of individual bacterial species on diatom aggregation have not been explored thus far.

A better understanding of the molecular basis of bacteria-diatom interactions that lead to marine snow formation is currently gained by establishing a bilateral model system, for which $M$. adhaerens sp. nov. HP15 serves as the bacterial partner of the easy-to-culture diatom, T. weissflogii [3]. Herein, we present a set of features for $M$. adhaerens sp. nov. HP15 (Table 1) together with its annotated complete genomic sequence, and a detailed analysis of its flagella-associated genes. 


\section{Classification and features}

M. adhaerens sp. nov. strain HP15 is a motile, Gram-negative, non-spore-forming rod (Figure 1). Based on its 16S rRNA sequence, strain HP15 was assigned to the Marinobacter genus of Gammaproteobacteria. Two other Marinobacter species were identified based on their interactions with eukaryotes - M. algicola isolated from dinoflagellate cultures [20] and M. bryozoorum derived from
Bryozoa [21]. The 16S rRNA gene of strain HP15 is most closely related to those of the type strains of M. flavimaris (99\%), M. salsuginis (98\%) and $M$. algicola (96\%). These four type strains form a discrete cluster in the phylogenetic tree (Figure 2). In contrast, DNA-DNA hybridization experiments revealed that the genome of $M$. adhaerens sp. nov. HP15 showed about $64 \%$ binding to that of $M$. flavimaris [1], which is below the generally accepted species differentiation limit of $70 \%$ [25].

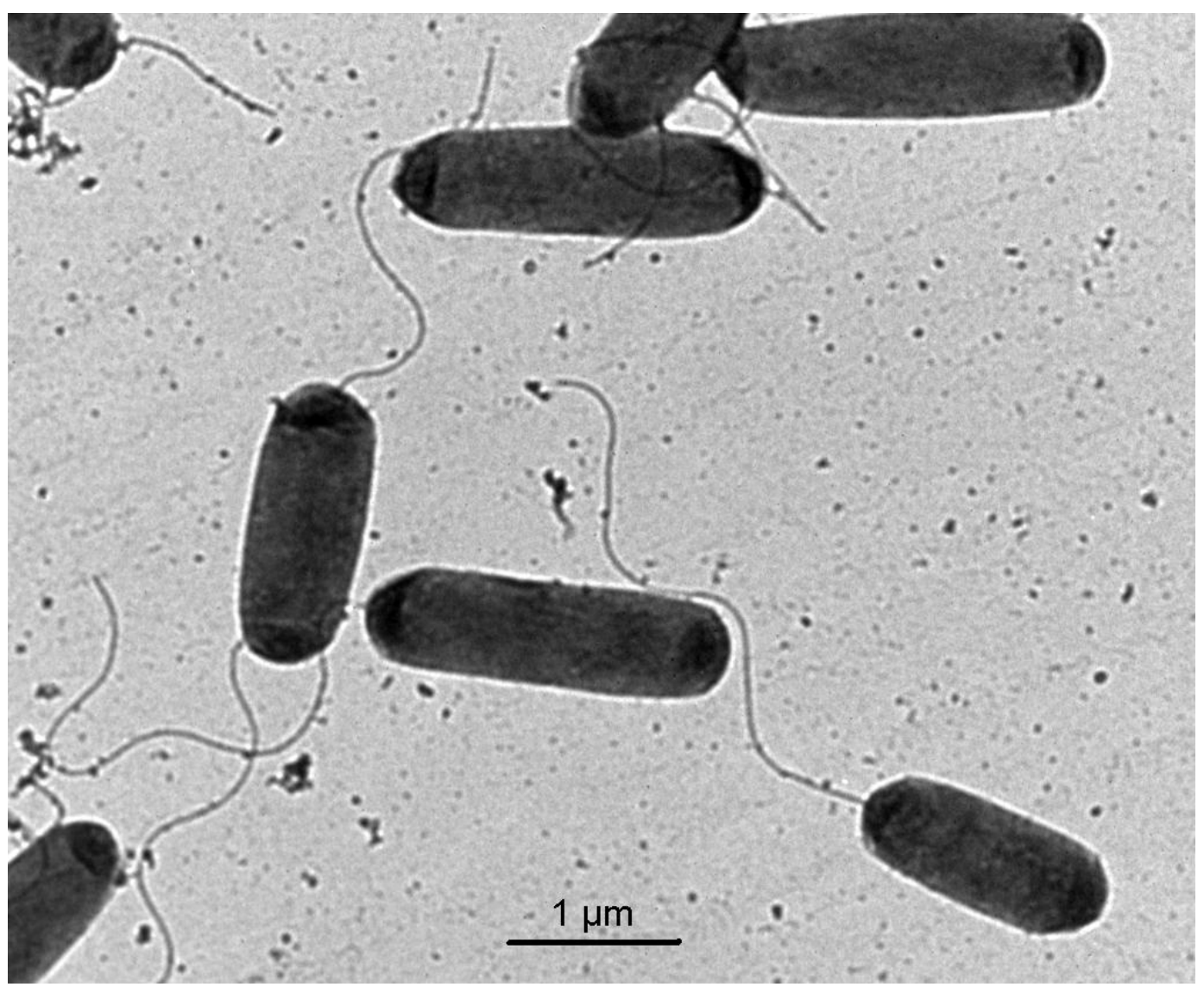

Figure 1. Transmission electron micrograph of $M$. adhaerens sp. nov. strain HP15.

\section{Chemotaxonomy}

Strain HP15 can grow in artificial sea water with a nitrogen-to-phosphorus ratio of 15:1 supplemented with glucose as the sole carbon source. In presence of diatom cells but without glucose, HP15 utilized diatom-produced carbohydrates as sole source of carbon. Furthermore, $M$. adhaerens sp. nov. HP15 differed from $M$. flavimaris and other Marinobacter species in a number of chemotaxonomic properties, such as utilization of glycerol, fructose, lactic acid, gluconate, alanine, and glutamate [1]. Additionally, strain HP15 showed a unique fatty acid composition pattern.

\section{Genome sequencing and annotation Genome project history}

$M$. adhaerens HP15 was selected for sequencing because of its phylogenetic position, its particular feature as a diatom-interacting marine organism [3], and its feasible genetic accessibility to act as a model organism. The respective genome project is deposited in the Genome OnLine Database [19] and the complete genome sequence in GenBank. The main project information is summarized in Table 2. 


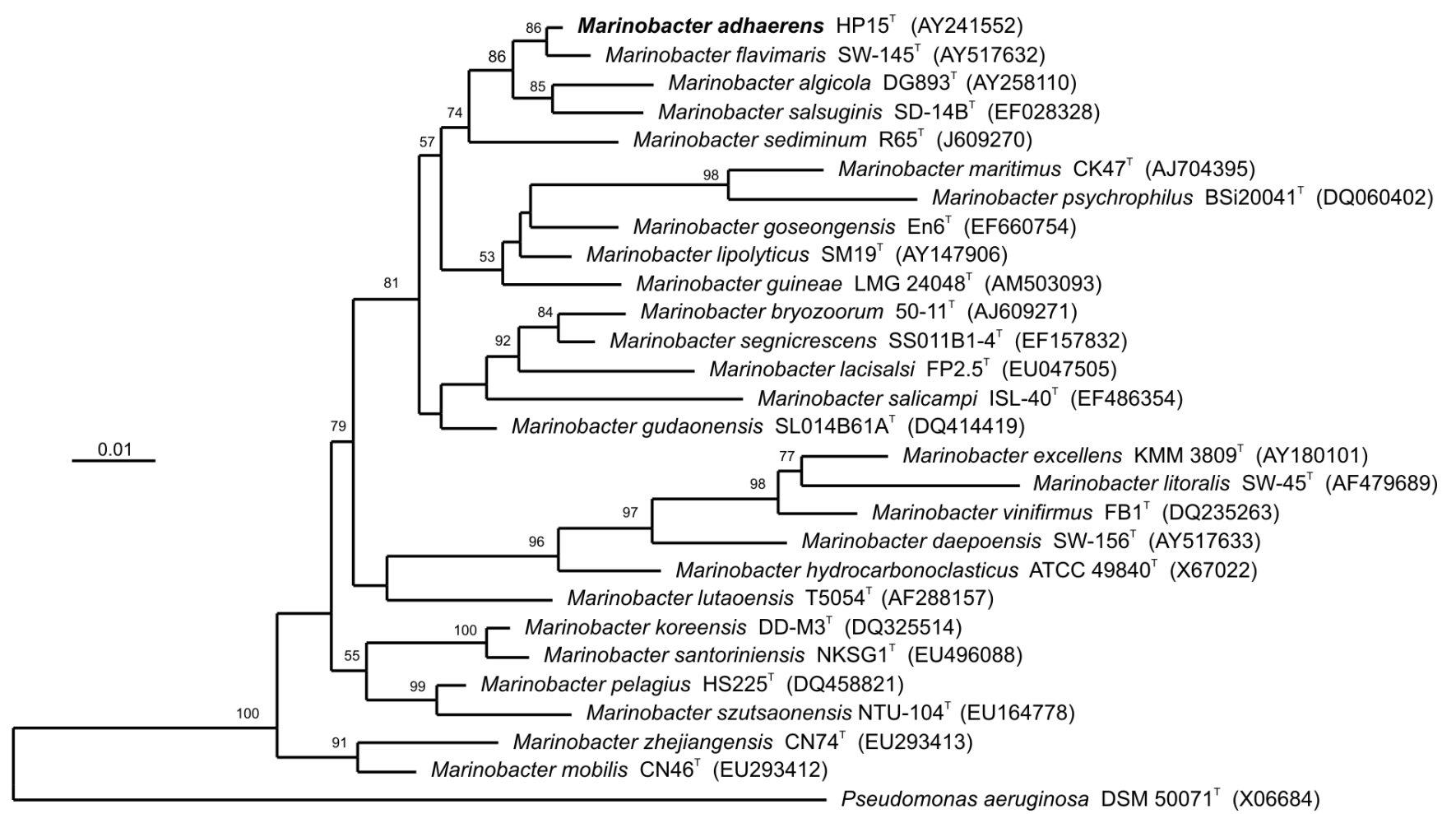

Figure 2. Maximum likelihood phylogenetic tree based on 16S rRNA sequences of $M$. adhaerens type strain (HP15) plus all type strains of the genus Marinobacter and the type species of the neighbor order Pseudomonadales. Sequence selection and alignment improvements were carried out using the Living Tree Project database [22] and the ARB software package [23]. The tree was inferred from 1,531 alignment positions using RAxML [24] with GTRGAMMA model. Support values from 1,000 bootstrap replicates are displayed above branches if larger than $50 \%$. The scale bar indicates substitutions per site.

\section{Growth conditions and DNA isolation}

M. adhaerens sp. nov. HP15 was grown in $100 \mathrm{ml}$ Marine Broth medium [26] at $28^{\circ} \mathrm{C}$. A total of 23 $\mu \mathrm{g}$ DNA was isolated from the cell paste using a Qiagen DNeasy Blood and Tissue Kit (Qiagen, Hilden, Germany) according to the manufacturer's instructions.

\section{Genome sequencing and assembly}

The Marinobacter adhaerens sp. nov. HP15 genome was sequenced at AGOWA (AGOWA GmbH, Berlin, Germany) using the 454 FLX Ti platform of 454 Life Sciences (Branford, CT, USA). The sequencing library was prepared according to the 454 instructions from genomic $M$. adhaerens sp. nov. HP15 DNA with a final concentration of 153 $\mathrm{ng} / \mu \mathrm{l}$. Sequencing was carried out on a quarter of a 454 picotiterplate, yielding 258.645 reads with an average length of $405 \mathrm{bp}$, totaling to almost $105 \mathrm{Mb}$. These reads were assembled using the Newbler assembler version 2.0.00.22 (Roche), resulting in 253.285 fully and 4.763 partially assembled reads, leaving 932 singletons, 226 repeats and 371 outliers. The assembly comprised 112 contigs, with 40 exceeding 500 bp. The latter comprised more than $4.6 \mathrm{Mb}$, with an average contig size of almost $116 \mathrm{~kb}$ and a longest contig of more than $1.2 \mathrm{Mb}$. Gaps between contigs were closed in a conventional PCR-based gap closure approach, resulting in a fully closed circular chromosome of $4.421 .911 \mathrm{bp}$, and two plasmids of $187.465 \mathrm{bp}$ and $42.349 \mathrm{bp}$, respectively. Together all sequences provided $22.5 \times$ coverage of the genome. The error rate of the completed genome sequence is about 3 in 1,000 (99.7\%). 
Table 1. Classification and general features of M. adhaerens sp. nov. HP15 according to the MIGS recommendations [9]

\begin{tabular}{|c|c|c|c|}
\hline MIGS ID & Property & Term & Evidence code \\
\hline & \multirow{8}{*}{ Current classification } & Domain Bacteria & TAS [10] \\
\hline & & Phylum Proteobacteria & TAS [11] \\
\hline & & Class Gammaproteobacteria & TAS $[12,13]$ \\
\hline & & Order Alteromonadales & TAS $[12,14]$ \\
\hline & & Family Alteromonadaceae & TAS [15-17] \\
\hline & & Genus Marinobacter & TAS $[1,18]$ \\
\hline & & Species Marinobacter adhaerens & TAS [1] \\
\hline & & Type strain HP15 & TAS [1] \\
\hline & Gram stain & negative & IDA \\
\hline & Cell shape & rod-shaped & IDA \\
\hline & Motility & motile, single polar flagellum & IDA \\
\hline & Sporulation & non-sporulating & NAS \\
\hline & Temperature range & mesophilic & IDA \\
\hline & Optimum temperature & $34-38^{\circ} \mathrm{C}$ & IDA \\
\hline & Salinity & 0.4-10 g NaCl/l (optimum/growth within 1 day) & IDA \\
\hline \multirow[t]{3}{*}{ MIGS-22 } & Oxygen requirement & strictly aerobic & IDA \\
\hline & Carbon source & $\begin{array}{l}\text { dextrin, Tween } 40 \text { and } 80 \text {, pyruvic acid methyl } \\
\text { ester, succinic acid mono-methyl-ester, cis- } \\
\text { aconitic acid, } \beta \text {-hydroxybutyric acid, } \gamma \text { - } \\
\text { hydroxybutyric acid, } \alpha \text {-keto glutaric acid, } \alpha \text {-keto } \\
\text { valeric acid, D, L-lactic acid, bromosuccinic acid, } \\
\text { L-alaninamide, D-alanine, L-alanine, L-glutamic } \\
\text { acid, L-leucine and L-proline }\end{array}$ & IDA \\
\hline & Energy source & chemoorganoheterotrophic & IDA \\
\hline MIGS-6 & Habitat & sea water & IDA \\
\hline MIGS-15 & Biotic relationship & free-living and particle-associated & TAS [2] \\
\hline MIGS-13 & Culture deposition no. & DSM 23420 & IDA \\
\hline \multirow[t]{3}{*}{ MIGS-14 } & Pathogenicity & none & NAS \\
\hline & Biosafety level & 1 & NAS \\
\hline & Isolation & marine aggregates $(0.1-1 \mathrm{~mm})$ & TAS [2] \\
\hline MIGS-4 & Geographic location & German Wadden Sea & TAS [2] \\
\hline MIGS-4.1 & Latitude & $53^{\circ} 43^{\prime} 20^{\prime \prime} \mathrm{N}$ & TAS [2] \\
\hline MIGS-4.2 & Longitude & $07^{\circ} 43^{\prime} 20^{\prime \prime} \mathrm{E}$ & TAS [2] \\
\hline MIGS-4.3 & Depth & surface waters & TAS [2] \\
\hline MIGS-4.4 & Altitude & sea level & TAS [2] \\
\hline MIGS-5 & time & 15 June 2000 & TAS [2] \\
\hline
\end{tabular}

Evidence codes - IDA: inferred from Direct Assay (first time in publication); TAS: Traceable Author Statement (i.e., a direct report exists in the literature); NAS: Non-traceable Author Statement (i.e., not directly observed for the living, isolated sample, but based on a generally accepted property of the species, or anecdotal evidence). These evidence codes are from the Gene Ontology project [19]. If evidence code is IDA, then the property was directly observed for a live isolate by one of the authors or an expert mentioned in the acknowledgements. 
Table 2: Genome sequencing project information for $M$. adhaerens sp. nov. HP15

\begin{tabular}{lll}
\hline MIGS ID & Property & Term \\
\hline MIGS-31 & Finishing quality & Finished \\
MIGS-28 & Library used & 454 pyrosequencing standard library \\
MIGS-29 & Sequencing platforms & 454 FLX Ti \\
MIGS-31.2 & Sequencing coverage & $22.5 \times$ pyrosequencing \\
MIGS-30 & Assemblers & Newbler version 2.0.00.22 \\
MIGS-32 & Gene calling method & GLIMMER v3.02, tRNAScan-SE \\
& & CP001978 (chromosome) \\
& Genbank ID & CP001979 (pHP-42) \\
& & CP001980 (pHP-187) \\
& Genbank Date of Release & September 18, 2010 \\
& GOLD ID & Gi06214 \\
& NCBI project ID & 46089 \\
& Database: IMG & pending \\
& Project relevance & Marine diatom-bacteria interactions \\
\hline
\end{tabular}

\section{Genome annotation}

Potential protein-coding genes were identified using GLIMMER v3.02 [27], transfer RNA genes were identified using tRNAScan-SE [28] and ribosomal RNA genes were identified via BLAST searches [29] against public nucleotide databases. The annotation of the genome sequence was performed with the GenDB v2.2.1 system [30]. For each predicted gene, similarity searches were performed against public sequence databases (nr, SwissProt, KEGG) and protein family databases (Pfam, InterPro, COG). Signal peptides were predicted with SignalP v3.0 [31,32] and transmembrane helices with TMHMM v2.0 [33]. Based on these observations, annotations were derived in an automated fashion using a fuzzy logic-based approach [34]. Finally, the predictions were manually checked with respect to missing genes in intergenic regions and putative sequencing errors, and the annotations were manually curated using the Artemis 11.3.2 program and refined for each putative gene [35].

\section{Genome properties}

The genome of strain HP15 comprises three circular replicons: the 4,422,725 bp chromosome and two plasmids of $\sim 187 \mathrm{~kb}$ and $\sim 42 \mathrm{~kb}$, respectively (Table 3A and Figure 3). The genome possesses a $56.9 \%$ GC content (Table 3B). Of the 4,482 predicted genes, 4,422 were protein coding genes, and 60 RNAs; 391 pseudogenes were also identified. The majority of the protein-coding genes $(67.5 \%)$ were assigned with a putative function, while those remaining were annotated as hypothetical proteins. The distribution of genes into COGs functional categories is presented in Table 4.

Table 3A. Genome composition for M. adhaerens HP15

\begin{tabular}{lcll}
\hline Label & Size $\mathbf{( M b )}$ & Topology & RefSeq ID \\
\hline Chromosome $^{\S}$ & 4.423 & circular & CP001978 \\
Plasmid pHP-187 $^{\star}$ & 0.187 & circular & CP001980 \\
Plasmid pHP-42* & 0.042 & circular & CP001979 \\
\hline
\end{tabular}

$\$$ Number of protein-coding genes: 4,180; ${ }^{\circledR}$ Number of protein-coding genes: 178 ;

* Number of protein-coding genes: 52 
Table 3B. Genome statistics for M. adhaerens HP15

\begin{tabular}{lrr}
\hline Attribute & Value & \% $^{\text {of total }} \mathbf{a}^{\mathbf{a}}$ \\
\hline Genome size (bp) & $4,651,725$ & \\
DNA Coding region (bp) & $4,178,502$ & 89.8 \\
DNA G+C content (bp) & $2,644,970$ & 56.9 \\
Number of replicons & 3 & \\
Extrachromosomal elements & 2 & \\
Total genes & 4,410 & \\
tRNA genes & 51 & 1.16 \\
5S rRNA genes & 3 & 0.07 \\
16S rRNA genes & 3 & 0.07 \\
23S rRNA genes & 3 & 0.07 \\
Protein-coding genes & 4,355 & 98.66 \\
Genes assigned to COGs & 3,027 & 67.54 \\
Genes with Pfam domains & 2,918 & 65.1 \\
1 Pfam domain & 2,041 & 45.54 \\
2 Pfam domains & 598 & 13.34 \\
3 Pfam domains & 194 & 4.33 \\
4 or more Pfam domains & 85 & 1.9 \\
Genes with signal peptides & 765 & 17.07 \\
Genes with transmembrane helices & 1,043 & 23.27 \\
1 transmembrane helix & 341 & 7.61 \\
2 transmembrane helices & 154 & 3.44 \\
3 transmembrane helices & 72 & 1.61 \\
4 or more transmembrane helices & 476 & 10.62 \\
Genes in paralogous clusters & 570 & 12.72 \\
Genes with 1 paralog & 364 & 8.12 \\
Genes with 2 paralogs & 63 & 1.41 \\
Genes with 3 paralogs & 26 & 0.58 \\
Genes with 4 or more paralogs & 117 & 2.61 \\
Pseudo/hypothetical genes & 391 & 8.72 \\
Conserved hypothetical genes & 668 & 14.90 \\
Genes for function prediction & 3,363 & 75.03 \\
\hline
\end{tabular}

a) The total is based on either the size of the genome in base pairs or the total number of protein coding genes in the annotated genome.

b) Also includes 54 pseudogenes and 5 other genes.

\section{Flagella-associated gene clusters of M. adhaerens HP15}

Because M. adhaerens HP15 was experimentally shown to adhere to diatom cells, gene clusters coding for secretion, assembly, and mechanistic function of the polar flagellum were analyzed in detail (Figure 4). Besides several other chemotactic mechanisms and various cell surface interactions, bacterial flagella and other cell appendages had previously been shown to be instrumental for chemotactic movement towards and adhesion to biotic surfaces [36,37]. The amino acid sequences of proteins encoded by the three identified gene clusters showed significant similarities to orthologous and experimentally well-described gene products of $P$. aeruginosa PA01 and various other bacterial species as determined by BLASTP algorithm comparison using the Blosum 62 substitution matrix [29]. Not surprisingly, hook and motor switch complex components were most conserved. However, gene products involved in flagellar filament formation encoded by Cluster II also showed 53 to $78 \%$ similarity to the respective PAO1 proteins. Mutagenesis of flagella-associated genes of $M$. adhaerens HP15 will be carried out in the near future to study the role of flagella in bacteria-diatom interactions and to further our understanding of the cell-to-cell communication between those organisms. 

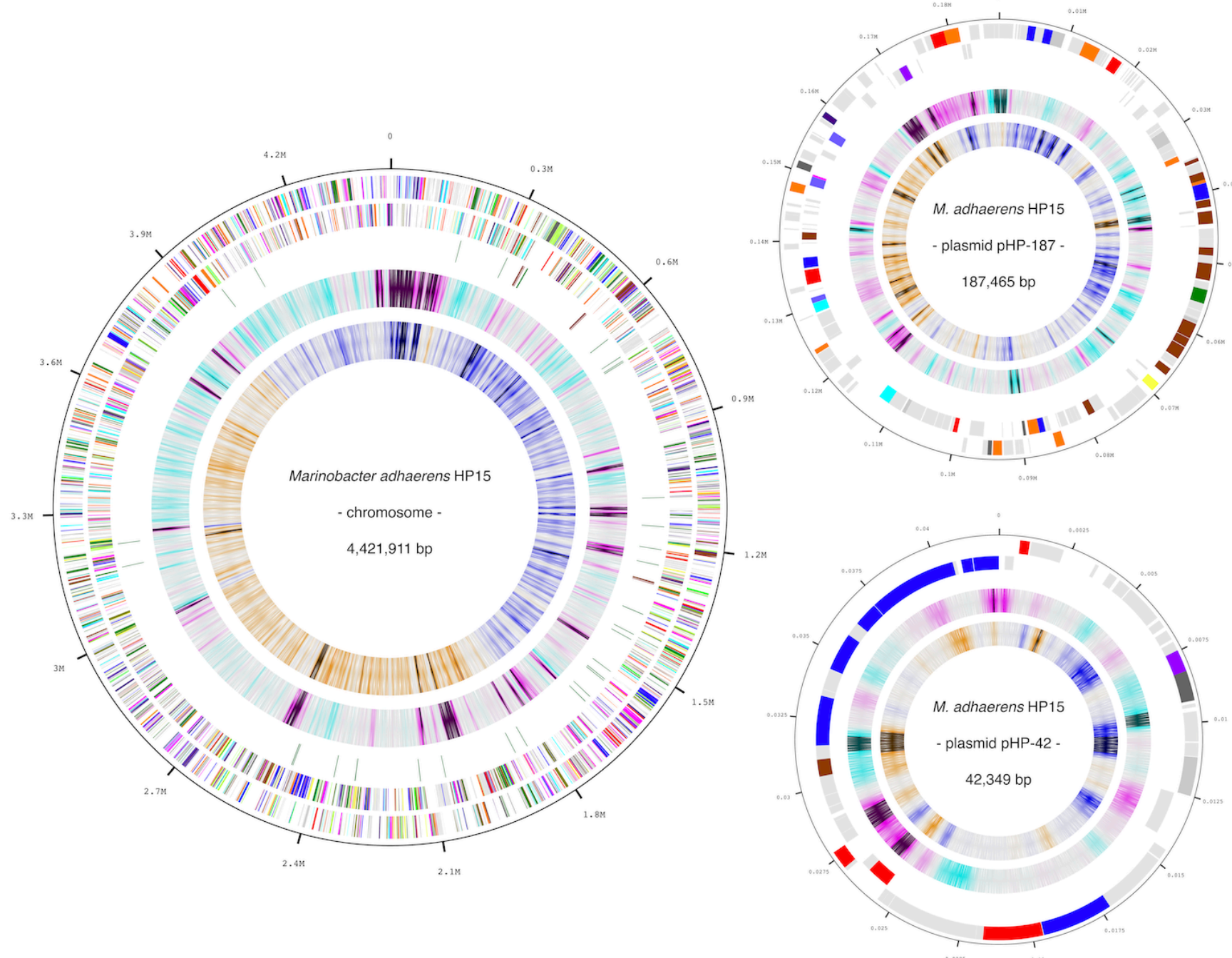

Circle 1: Genes on the forward strand, colored by COG category Circle 2: Genes on the reverse strand, colored by $\mathrm{COG}$ category

$\square$ - no COG hit

re and biogenesis

K-transcription

D - cell division and chromosome partitioning

O- postrranslational modification, protein turnover, chaperones

M - cell envelope biogenesis, outer membrane

$\mathrm{N}$ - cell motility and secretion

$\mathrm{P}$ - inorganic ion transport and metabolism

$\square \quad T$ - signal transduction mechanisms

C - energy production and conversion

G- carbohydrate transport and metabolism

E. amino acid transport and metabolism

F- nucleotide transport and metabor

H-coenzyme metabolism

1- lipid metabolism

Q - secondary metabolites bi

sis, transport and catabolism

R - general function prediction

Circle 3: RNA genes

tRNA genes

Circle 4: GC content

chromosome (10,000 bp sliding window)

pHP-187 (1,000 bp sliding window)

- PHP-42 (1,000 bp sliding window

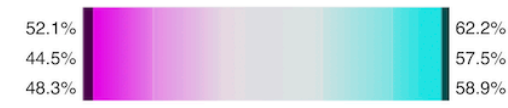

Circle 5: GC skew

chromosome (10,000 bp sliding window)

pHP-187 (1,000 bp sliding window)

pHP-42 (1,000 bp sliding window)

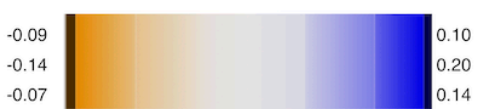

Figure 3. Graphical circular maps of the genome and the two plasmids of HP15. From outside to the center: Genes on forward strand (color by COG categories), Genes on reverse strand (color by COG categories), RNA genes (tRNAs green, rRNAs red, other RNAs black), GC content, GC skew. 
Table 4. Number of genes associated with the 21 general COG functional categories

\begin{tabular}{|c|c|c|c|}
\hline Code & Value & $\% \operatorname{age}^{a}$ & Description \\
\hline$J$ & 162 & 3.7 & Translation \\
\hline A & 0 & 0 & RNA processing and modification \\
\hline K & 161 & 3.6 & Transcription \\
\hline $\mathrm{L}$ & 132 & 3 & Replication, recombination and repair \\
\hline B & 0 & 0 & Chromatin structure and dynamics \\
\hline $\mathrm{D}$ & 32 & 0.7 & Cell cycle control, mitosis and meiosis \\
\hline Y & 0 & 0 & Nuclear structure \\
\hline V & 0 & 0 & Defense mechanisms \\
\hline $\mathrm{T}$ & 199 & 4.5 & Signal transduction mechanisms \\
\hline M & 151 & 3.4 & Cell wall/membrane biogenesis \\
\hline $\mathrm{N}$ & 166 & 3.8 & Cell motility \\
\hline Z & 0 & 0 & Cytoskeleton \\
\hline W & 0 & 0 & Extracellular structures \\
\hline$U$ & 0 & 0 & Intracellular trafficking and secretion \\
\hline $\mathrm{O}$ & 127 & 2.9 & Posttranslational modification, protein turnover, chaperones \\
\hline $\mathrm{C}$ & 192 & 4.3 & Energy production and conversion \\
\hline G & 82 & 1.9 & Carbohydrate transport and metabolism \\
\hline $\mathrm{E}$ & 254 & 5.7 & Amino acid transport and metabolism \\
\hline $\mathrm{F}$ & 51 & 1.1 & Nucleotide transport and metabolism \\
\hline $\mathrm{H}$ & 97 & 2.2 & Coenzyme transport and metabolism \\
\hline I & 141 & 3.2 & Lipid transport and metabolism \\
\hline$P$ & 138 & 3.1 & Inorganic ion transport and metabolism \\
\hline Q & 76 & 1.7 & Secondary metabolites biosynthesis, transport and catabolism \\
\hline $\mathrm{R}$ & 330 & 7.5 & General function prediction only \\
\hline S & 251 & 5.7 & Function unknown \\
\hline \multirow[t]{2}{*}{-} & 285 & 6.4 & multiple COGs \\
\hline & 3,027 & 68.6 & Total \\
\hline- & 1,383 & 31.4 & Not in COGs \\
\hline
\end{tabular}

a) The total is based on the total number of protein coding genes in the annotated genome 


\section{Cluster I : basal body}
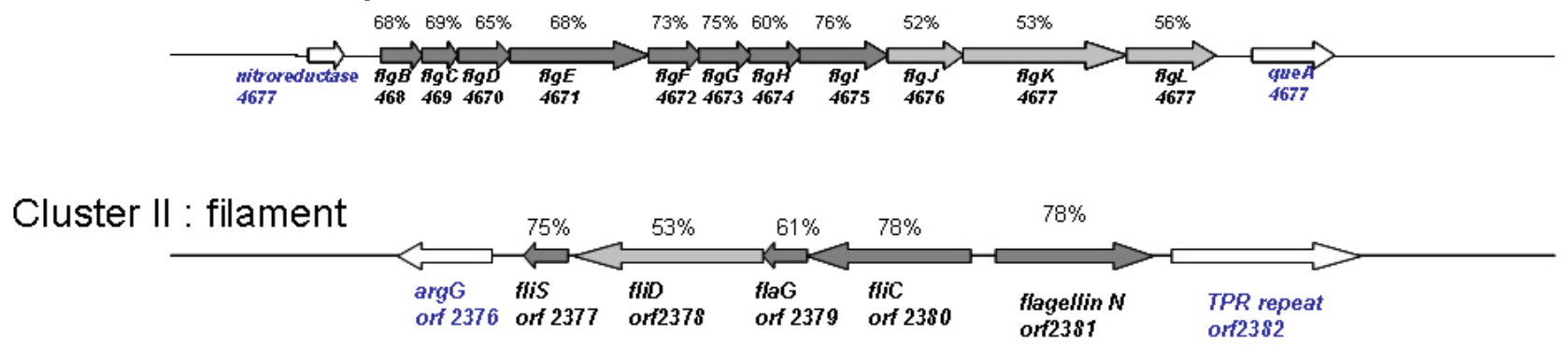

\section{Cluster III : hook and motor switch complex}
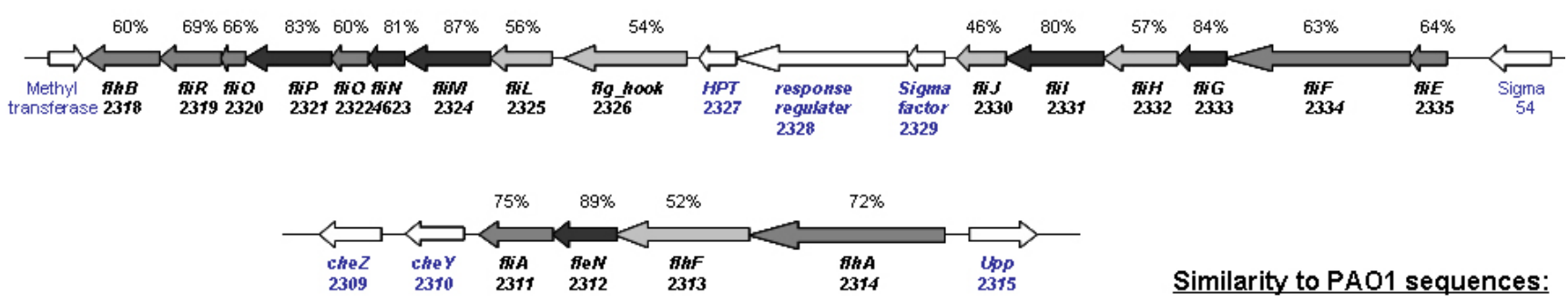

Similarity to PAO1 sequences:

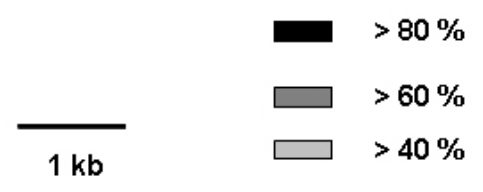

not flagellar associatated

Figure 4. Schematic presentation of the three flagella-associated gene clusters of M. adhaerens HP15 coding for the basal body, the filament, and the hook and motor switch complex. Identities to the respective orthologs in the genome of $P$. aeruginosa PAO1 are indicated by gray-scale code. Numbers of CDS are shown below gene names.

\section{Acknowledgements}

We thank Yannic Ramaye for help with TEM operation and Christian Quast for computer support. The work was

\section{References}

1. Kaeppel EC, Gärdes A, Seebah S, Grossart HP, Ullrich MS. Marinobacter adhaerens sp. nov., prominent in aggregate formation with the diatom Thalassiosira weissflogii. Int I Syst Evol Microbiol 2010; (Submitted).

2. Grossart HP, Schlingloff A, Bernhard M, Simon $M$, Brinkhoff T. Antagonistic activity of bacteria isolated from organic aggregates of the German Wadden Sea. FEMS Microbiol Ecol 2004; 47:387396. PubMed doi:10.1016/S01686496(03)00305-2

3. Gärdes A, Iversen M, Grossart H, Passow U, UIIrich MS. Diatom-associated bacteria are required for Thalassiosira weissflogii aggregation. ISME J financially supported by the Max Planck Society, the Helmholtz Foundation, and Jacobs University Bremen.

2010; (In press). PubMed doi:10.1038/ismej.2010.145

4. Fowler SW, Knauer GA. Role of large particles in the transport of elements and organic compounds through the oceanic water column. Prog Oceanogr 1986; 16:147-194. doi:10.1016/0079$\underline{6611(86) 90032-7}$

5. Alldredge AL, Silver MW. Characteristics, dynamics and significance of marine snow. Prog Oceanogr 1988; 20:41-82. doi:10.1016/00796611(88)90053-5

6. Passow U. Transparent exopolymer particles (TEP) in aquatic environments. Prog Oceanogr 2002; 55:287-333. doi:10.1016/S0079-6611(02)00138$\underline{6}$ 
7. Simon M, Grossart HP, Schweitzer B, Ploug H. Microbial ecology of organic aggregates in aquatic ecosystems. Aquat Microb Ecol 2002; 28:175211. doi:10.3354/ame028175

8. Verdugo P, Alldredge AL, Azam F, Kirchman DL, Passow U, Santschi PH. The oceanic gel phase: a bridge in the DOM-POM continuum, p. 67-85. Symposium on New Approaches in Marine Organic Biogeochemistry held in Honor of the Life and Science of John I Hedges. 2003; Elsevier Science Bv.

9. Field D, Garrity G, Gray T, Morrison N, Selengut J, Sterk P, Tatusova T, Thomson N, Allen MJ, Angiuoli SV. Towards a richer description of our complete collection of genomes and metagenomes: the "Minimum Information about a Genome Sequence" (MIGS) specification. Nat Biotechnol 2008; 26:541-547. PubMed doi:10.1038/nbt1360

10. Woese CR, Kandler O, Wheelis ML. Towards a natural system of organisms: proposal for the domains Archaea, Bacteria, and Eucarya. Proc Natl Acad Sci USA 1990; 87:4576-4579. PubMed doi:10.1073/pnas.87.12.4576

11. Garrity GM, Holt JG. The Road Map to the Manual. In: Garrity GM, Boone DR, Castenholz RW (eds), Bergey's Manual of Systematic Bacteriology, Second Edition, Volume 1, Springer, New York, 2001, p. 119-169.

12. List Editor. Validation of publication of new names and new combinations previously effectively published outside the IJSEM. List no. 106. Int J Syst Evol Microbiol 2005; 55:2235-2238. doi:10.1099/ijs.0.64108-0

13. Garrity GM, Bell JA, Lilburn T. Class III. Gammaproteobacteria class. nov. In: Garrity GM, Brenner DJ, Krieg NR, Staley JT (eds), Bergey's Manual of Systematic Bacteriology, Second Edition, Volume 2, Part B, Springer, New York, 2005, p. 1.

14. Bowman JP, McMeekin TA. Order X. Alteromonadales ord. nov. In: Garrity GM, Brenner DJ, Krieg NR, Staley JT (eds), Bergey's Manual of Systematic Bacteriology, Second Edition, Volume 2, Part B, Springer, New York, 2005, p. 443.

15. List Editor. Validation List no. 81. Validation of publication of new names and new combinations previously effectively published outside the IJSEM. Int J Syst Evol Microbiol 2001; 51:1229. PubMed

16. Ivanova EP, Mikhailov VV. A new family, Alteromonadaceae fam. nov., including marine proteobacteria of the genera Alteromonas, Pseudoalte- romonas, Idiomarina, and Colwellia. Microbiology 2001; 70:10-17. doi:10.1023/A:1004876301036

17. Ivanova EP, Flavier S, Christen R. Phylogenetic relationships among marine Alteromonas-like proteobacteria: emended description of the family Alteromonadaceae and proposal of Pseudoalteromonadaceae fam. nov., Colwelliaceae fam. nov., Shewanellaceae fam. nov., Moritellaceae fam. nov., Ferrimonadaceae fam. nov., Idiomarinaceae fam. nov. and Psychromonadaceae fam. nov. Int J Syst Evol Microbiol 2004; 54:17731788. PubMed doi:10.1099/ijs.0.02997-0

18. Gauthier MJ, Lafay B, Christen R, Fernandez L, Acquaviva M, Bonin P, Bertrand JC. Marinobacter hydrocarbonoclasticus gen. nov., sp. nov., a new, extremely halotolerant, hydrocarbon-degrading marine bacterium. Int / Syst Bacteriol 1992; 42:568-576. PubMed doi:10.1099/00207713-424-568

19. Liolios K, Mavromatis K, Tavernarakis N, Kyrpides NC. The Genome On Line Database (GOLD) in 2007: Status of genomic and metagenomic projects and their associated metadata. Nucleic Acids Res 2008; 36:D475-D479. PubMed doi:10.1093/nar/gkm884

20. Green DH, Bowman JP, Smith EA, Gutierrez T, Bolch CJS. Marinobacter algicola sp. nov., isolated from laboratory cultures of paralytic shellfish toxin-producing dinoflagellates. Int J Syst Evol Microbiol 2006; 56:523-527. PubMed doi:10.1099/ijs.0.63447-0

21. Romanenko LA, Schumann P, Rohde M, Zhukova NV, Mikhailov VV, Stackebrandt E. Marinobacter bryozoorum sp. nov. and Marinobacter sediminum sp. nov., novel bacteria from the marine environment. Int J Syst Evol Microbiol 2005; 55:143148. PubMed doi:10.1099/ijs.0.63258-0

22. Yarza P, Richter M, Peplies J, Euzéby J, Amann R, Schleifer KH, Ludwig W, Glöckner FO, RossellóMóra R. The All-Species Living Tree Project: a $16 \mathrm{~S}$ rRNA-based phylogenetic tree of all sequenced type strains. Syst Appl Microbiol 2008; 31:241-250. PubMed doi:10.1016/j.syapm.2008.07.001

23. Ludwig W, Strunk O, Westram R, Richter L, Meier H, Yadhukumar A, Buchner T, Lai S, Steppi G, Jobb W, et al. ARB: a software environment for sequence data. Nucleic Acids Res 2004; 32:13631371. PubMed doi:10.1093/nar/gkh293

24. Stamatakis A. RAxML-VI-HPC: maximum likelihood-based phylogenetic analyses with thousands of taxa and mixed models. Bioinformatics 2006; 
22:2688. PubMed

doi:10.1093/bioinformatics/btl446

25. Wayne LG, Brenner DJ, Colwell RR, Grimont PAD, Kandler O, Krichevsky MI, Moore LH, Moore WEC, Murray RGE, Stackebrandt E, et al. Report of the ad hoc committee on reconciliation of approaches to bacterial systematics. Int J Syst Evol Microbiol 1987; 37:463.

26. Zobell CE. Studies on marine bacteria. I. The cultural requirements of heterotrophic aerobes. J Mar Res 1941; 4:42-75.

27. Delcher AL, Bratke KA, Powers EC, Salzberg SL. Identifying bacterial genes and endosymbiont DNA with Glimmer. Bioinformatics 2007;

23:673-679. PubMed doi:10.1093/bioinformatics/btm009

28. Lowe TM, Eddy SR. tRNAscan-SE: a program for improved detection of transfer RNA genes in genomic sequence. Nucleic Acids Res 1997; 25:955-964. PubMed doi:10.1093/nar/25.5.955

29. Altschul SF, Gish W, Miller W, Myers EW, Lipman DJ. Basic local alignment search tool. J Mol Biol 1990; 215:403-410. PubMed

30. Meyer F, Goesmann A, McHardy AC, Bartels D, Bekel T, Clausen J, Kalinowski J, Linke B, Rupp O, Giegerich R, Puhler A. GenDB--an open source genome annotation system for prokaryote genomes. Nucleic Acids Res 2003; 31:21872195. PubMed doi:10.1093/nar/gkg312

31. Emanuelsson O, Brunak S, Von Heijne G, Nielsen $\mathrm{H}$. Locating proteins in the cell using TargetP,
SignalP and related tools. Nat Protoc 2007;

2:953-971. PubMed doi:10.1038/nprot.2007.131

32. Nielsen H, Brunak S, Von Heijne G. Machine learning approaches for the prediction of signal peptides and other protein sorting signals. Protein Eng 1999; 12:3-9. PubMed doi:10.1093/protein/12.1.3

33. Krogh A, Larsson B, Von Heijne G, Sonnhammer EL. Predicting transmembrane protein topology with a hidden Markov model: application to complete genomes. J Mol Biol 2001; 305:567580. PubMed doi:10.1006/jmbi.2000.4315

34. Quast C. MicHanThi - design and implementation of a system for the prediction of gene functions in genome annotation projects. Master Thesis 2006 (Available on request).

35. Rutherford K, Parkhill J, Crook J, Horsnell T, Rice P, Rajandream MA, Barrell B. Artemis: sequence visualization and annotation. Bioinformatics 2000; 16:944-945. PubMed doi:10.1093/bioinformatics/16.10.944

36. O'Toole GA, Kolter R. Flagellar and twitching motility are necessary for Pseudomonas aeruginosa biofilm development. Mol Microbiol 1998; 30:295-304. PubMed doi:10.1046/j.13652958.1998.01062.x

37. Pallen MJ, Matzke NJ. From The Origin of Species to the origin of bacterial flagella. Nat Rev Microbiol 2006; 4:784-790. PubMed doi:10.1038/nrmicro1493 